\title{
Ancient and Current Toponomy of Asia Minor
}

\author{
Asst. Prof. Dr. Mustafa Arslan \\ Selcuk University Beyşehir Ali Akkanat Faculty of Tourism \\ muarslan@selcuk.edu.tr
}

\section{Doi:10.5901/jesr.2014.v4n4p455}

\begin{abstract}
Strabo, the geographer, was born (64/63-23? AD) in Amesia in Asia Minor. Today Amasia is called as Amasya in Anatolia. His book, the Geography, is an important ancient source for the toponomy of Anatolia. He described some parts of Asia Minor in his books XII to XIV. Historical conditions have changed since he wrote his book. As Anatolia is a very important peninsula like a cultural bridge between Europe and Asia, many ethnic groups of people have settled here or affected the culture of the region. At least Strabo's Asia Minor has become Anatolia or Anadolu in Turkish. In addition to these, thousands of settlements were renamed in 1950 and 1960s. The programme for renaming the settlements also changed original Turkish names. Despite of all the changes in the history and the toponomy of Asia Minor-Anatolia, names of some settlements have survived and are still in use with little or no change in sound. In this paper, the toponomy of Strabo's work and the toponomy of current Anatolia are compared and the unchanged or little changed place names are studied.
\end{abstract}

Keywords: Asia Minor, Anatolia, Ancient Geography, Place Names.

\section{Introduction}

Strabo the geographer was a native of Anatolia and a Greek citizen from Amasia in Pontus region. The meaning of his name is "squinty" in Greek. He was born in a leading family of the region (Koelsch, 2004: 503) in 63 B.C. and died in his hometown in Amasia in 23 A.D (Richards, 1941: 80). He wrote his Geography in his declining years in Amasia (Pothecary, 2002: 388). His book was written by the use of written sources but he mentioned the sources from his point of view (Vliet, 2003: 259). General view on the place where he wrote his book is his hometown, Amasia (Ridgeway, 1888: 84). But there are two views on writing period of his book; there were two editions written in different times or there was only one edition written in a single period of time(Dueck, 1999: 467). Strabo aimed to introduce the Greek world to Roman people by his book; Geography (Koelsch, 2004: 504). As a result we have a very vast source for the geography of ancient world. His XII., XIII., and XIV. books are about Anatolia, but not only about the geography of Anatolia but also about the history of it (Strabon, 2012: 18).

Anatolia was called Asia or Asia Minor in ancient times. The date of appearance of the names "Asia and Asia Minor" and the regions they comprise are not very clear (Sevin, 2001:2). But the place names of Anatolia were mostly based on Hittite and pre-Hellenic place names. Their pronunciations have changed but they survived up to present. Lukkuwania became Lycaonia, Lukka became Lycia, Asuwa became Asia (Bahar, 2005:156), Milawatas became Miletos (Garstang, 1943: 42), Apasas became Ephesus (Macqueen, 1968: 175) and Tarzi became Tarsus (Sayce, 1923: 49).

During the Strabo's age Greek and Latin were the main languages, but on the other hand there were other regional and local languages such as Phrygan, Lycian, Lydian, Luwian and Pisidian. When Greeks arrived in or took the possession of a town they used to change the names of the towns just in pronunciation to give them a Greek sound (Albright, 1925: 20). This was one of the major factors for the survival of the place names. But Colonel Leake (1777-1860) pointed out that names of ancient places were not in use during his visit to Asia Minor (Wagstaff, 1987: 28). May be, he expected to find more ancient place names being used by the locals, especially by Christian citizens. Contrary to Leake's observations in Asia Minor, Greece which was ruled by Turks for a long time protected her Greek nomenclature and Greek names gathered mostly on the coasts of Anatolia such as Smyrna, Pergamus, Magnesia, Phocaea and Spylum (Clarke, 1867: 181-2).

The Greek effect which began mostly by Alexander the great lasted by the defeat of Byzantine at Manzikert in Asia Minor (Charanis, 1975: 9, 18). As a result of this event, Greek population of Asia Minor moved to border places (Clarke, 1866: 157).

Books XII, XIII and XIV of Strabo's Geographika were examined carefully from Turkish translation edition of Pekman for this study and names of provinces, towns, mountains and rivers matching with the names in the books were determined. Later they were checked with the ones in "Dictionary of Greek and Roman Geography" of William Smith. 


\section{Provinces in Turkey Mentioned by Strabo}

There are eighty-one provinces in modern Turkey. It was seen that names of 18 provinces were derived from their ancient names. This means, about $22 \%$ province names have survived since Strabo or earlier than him. Turkish equivalents of the names were given together with the ancient ones in an alphabetical order. These are:

1- Amasia - Amasya: It was a city in Pontus region on river Iris. Amasia was the birth place of Strabo and residence of Pontus princes (Smith I, 1854: 117).

2- Amisus - Samsun: It was a city of Pontus in Asia Minor on the west coast of Amisenus Bay (Smith I, 1854: 122).

3- Ancyra - Ankara: The capital of Turkish Republic in Central Anatolia. It was a city of Galatia but originally belonged to Phrygia region. Its founder is not known but its mythical founder is accepted as Midas (Smith I, 1854: 133).

4- Attaleia - Antalya: A touristic city on the south coast of Turkey. It was in Pamphylia region during Strabo's time. Its founder is Attalus II. Philadelphus, Pergamum King (Smith I, 1854: 320).

5- Caesareia - Kayseri: It was a city in Cappadocia region on the foothills of mount Argaeus. It was the residence of kings of Cappodocia (Smith I, 1854: 469).

6- Cerasus - Giresun: The city was on the coast of Pontus in the west of Trapezus (Smith I, 1854: 590). Xenophon mentions Cerasus in Anabasis (5. 3) as the colony of Sinopeans in the territory of Colchis.

7- Cotiaeum, Cotiäeium - Kütahya: It was a town in Phrygia on a Roman road from Dorylaeum to Philadelphia (Smith I, 1854: 697).

8- Gangra - Çankırı: A Paphlagonian city in the south of Mount Olgasys. It was also the residence of Deiotarus who was the last king of Paphlagonia (Smith I, 1854: 974).

9- Garsaura - Aksaray: It was a small town in Cappadocia region (Smith I, 1854: 977). It is now called Aksaray.

10- Iconium - Konya: It was city in Lycaonia region. During Seljuk period it became the capital (Smith II, 1854:12). It was an important station on a very important west-east Roman road from Ephesus to Tarsos in Asia Minor (Sevin, 2001: 5). Being the capital of Seljuk Turks and a very religious place for Muslim Turks, its name surprisingly survived up to present.

11- Laodiceia - Ladik, Denizli: It was a city in the south-west of Phrygia in the east of Hierapolis (Smith II, 1854: 122). There are two more towns with the name Ladik in Turkey. The first is in Sarayönü County in Konya province which is known as Laodiceia Combusta and the second is a county in Samsun province.

12- Laranda - Larende, Karaman: It was an important town in Lycaonia in the south-east of Iconium (Smith II, 1854: 125).

13- Magnesia - Manisa: It was a city near Mount Sipylus that is why it was called as Magnesia ad Sipylus to distinguish from Magnesia on Maeander (Smith II, 1854: 252).

14- Melitene - Malatya: It was a city on the east border of Cappadocia (Smith II, 1854: 321). It is called Malatya in modern Turkey.

15- Prusa - Bursa: It was a Mysian city in the north of Mount Olympus (Smith II, 1854: 674). Its modern name is Bursa now.

16- Sebasteia - Sivas: It was in the south of Pontus, on the north bank of river Halys. It is called Sivas today (Smith II 1854, 946).

17- Sinope - Sinop: It was an important city in Paphlagonia on the coast of Euxine (Smith II, 1854: 1007). It is probably the least changed city name since the Strabo's age.

18- Trapezus - Trabzon: It was an important city of Pontus on the coast of Euxine which was founded by colonists from Sinope (Smith II, 1854: 1221). 


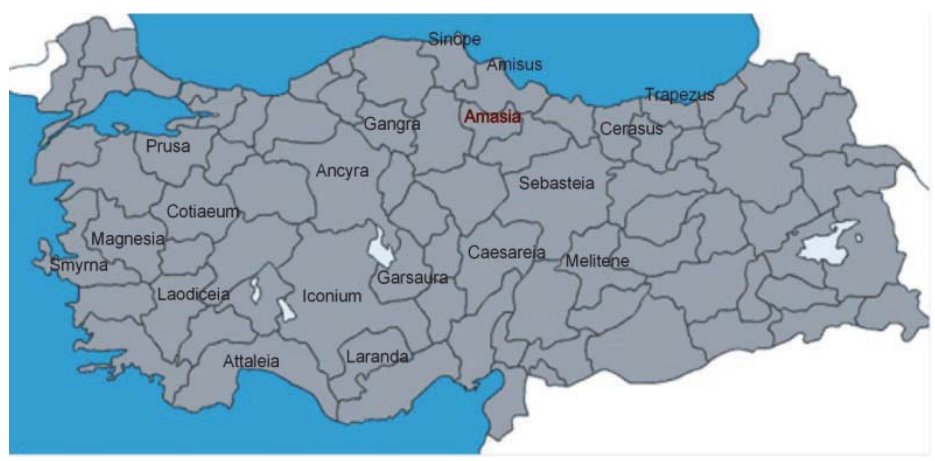

Figure 1: Provinces of Turkey with ancient names.

\section{Towns in Turkey Mentioned by Strabo}

There are twenty-two towns with ancient names in modern Turkey. I believe that there are more towns with ancient names in the country and more detailed studies are going to increase the number. The towns are:

1- Adramyttium - Edremit: It was a town in Mysia on the road from Hellesponts to Pergamum (Smith I, 1854: 25).

2- Alexandreia - İskenderun: There are several towns with the name Alexander in the world. It was called Alexandreia ad Issum to distinguish from the other towns with the same name. It was a town in the east of Gulf of Issus (Smith I, 1854: 102). The town has preserved its name originally since its foundation because equivalent of Alexander is İskender in Turkish.

3- Amastris - Amasra: It was a Paphlagonian city on a river with the same name (Smith I, 1854: 118).

4- Amorium - Emirdağ: A Phrygian city between Pessinus and Laoedicea (Smith I, 1854: 124). It preserved its ancient name as "Emir" in modern Emirdağ.

5- Anabura - Enevre: It is probably the smallest settlement in the study. It was situated in Phrygia (Smith I, 1854: 128) but Strabo mentions about it as a Pisidian town. It was localized in Enevre by Sterrett (Sterrett, 1888: 193).

6- Anemurium - Anamur: It is the southernmost settlement of Turkey. It was a Cilician city which was the nearest to Cyprus (Smith I, 1854: 136).

7- Callipolis - Gelibolu: It was a town in Thracia opposite Lampsacus (Smith I, 1854: 482).

8- Coloe - Kula: It is a town in Manisa Province, modern Kula. Koloe was a very popular name for the places in Greco-Roman Lydia (Lane, 1975: 105).

9- Coscinia - Çine: It was a small town in Caria (Smith I, 1854: 696). Its modern name is Çine.

10- Ephesus - Efes: It was a big city in Ionia (Smith I, 1854: 833), in the west of Turkey.

11- Lampsacus - Lapseki: It was an important Mysian city of Greeks on the Hellespont with an excellent harbor oppsite Callipolis (Smith II, 1854: 118).

12- Mylassa, Mylasa - Milas: It was the most important city of Caria. There were two Zeus temples in the city. It was also the residence of Carian Kings before the develeopment of Halikarnassos (Smith II, 1854: 385).

13- Pergamum - Bergama: It was a Mysian city in the West of Asia Minor (Smith II, 1854: 575). It is called Bergama in modern Turkey.

14- Phocaea - Foça: It was a city in the north of Ionia (Smith II, 1854: 603). It is one of the good examples of surviving ancient name with no or less change in pronunciation.

15- Phoenicus - Finike: A port city in Lycia, in the east of Patara (Smith II, 1854: 619).

16- Sagalassus - Ağlasun: It was an important town of Pisidia (Smith II, 1854: 873), during the reign of Alexander the Great (Arrian, I. 28).

17- Sardes - Sart: It was the ancient capital of Lydia in Western Asia Minor. It's stiuated between Tmolus Mountain and Hermus River (Smith II, 1854: 906).

18- Seleuceia, Seleucia - Selef: It was a Pisidian border city in the north of the region (Smith II, 1854: 954). It is another small town with Anabura in the same region.

19- Seleuceia, Seleucia - Silifke: It was an important city in Cilicia and founded by Seleucus I Nicator (Smith II, 
1854: 954).

20- Side - Side: It was a harbour town in Pamphylia in Asia Minor on the southern coast (Smith II, 1854: 994). Its name hasn't changed throughout the history.

21- Tarsus - Tarsus: Another unchanged place name like Side from Asia Minor. It was not only the leading city of its region -Cilicia- but also the whole Asia Minor in ancient history(Smith II, 1854: 1105-6).

22- Zela - Zile: It was a town in central Pontus, on the bank of river Iris. It is famous for Caesar's report "Veni, Vidi, Vici" (Smith II, 1854: 1337).

\section{Rivers in Turkey Mentioned by Strabo}

1- Euphrates - Firat: It is a big river in Western Asia in the east of Asia Minor. Tigris is the twin stream of Euphrate (Smith I, 1854: 875).

2- Maeander - Menderes: It is a very important river in Asia Minor. Its sources are in Celaenai in Phrygia (Smith II, 1854: 243).

3- Sangarius - Sakarya: It is an important river in the north-west of Turkey. Its sources are in Phrygia but flows into Euxine in Bithynia (Smith II, 1854:902).

4- Thermodon - Terme: It is a river in Pontus, in the region of Amazons (Smith II, 1854: 1161).

5- Mountains in Turkey Mentioned by Strabo

1- Amanus - Amanos: It's a part of Taurus Mountain chain in the south of Asia Minor, stretching the east of Issus Gulf (Smith I, 1854: 114).

2- Argaeus - Erciyes: It is a volcanic mountain in Cappadocia region (Smith I, 1854: 198). It is in Kayseri province today.

3- Olgassys - Ilgaz: It is mountain between Paphlagonia and Galatia, Halys and Sangarius (Smith II, 1854: 473).

4- Sipylus - Spil: It is mountain in Lydia between river Hermus and Smyrna (Smith II, 1854: 1011).

5- Taurus Mons - Toros Dağları: It is a great mountain range in Asia, in the south of Asia Minor (Smith II, 1854: 1115).

\section{Acknowledgements}

This study was supported by Selcuk University Scientific Research Projects Coordination Unit with 14701288 project number.

\section{References}

Albright, W., F., (1925). Philological Method in the Identification of Anatolian Place-Names. The Journal of Egyptian Archaeology. 11, $1 / 2,19-22$.

Arrian, (2005). İskender'in Seferleri (Translated by: M. Mete9, İstanbul: Idea Yayınları

Bahar, H., (2005). Eskiçağ Tarihi Ders Notları. Konya: Dizgi Ofset Matbaacılık.

Charanis, P., (1975). Cultural Diversity and the Breakdown of Byzantine Power in Asia Minor. Dumbarton Oaks Papers. 29, 1-20.

Clarke, H., (1866). On the Inhabitants of Asia Minor Previous to the Time of the Greeks. Transactions of the Ethnological Society of London. 4, 154-163.

Clarke, H., (1867). On the Topographical Nomenclature of Turkish Asia Minor. Journal of the Anthropological Society of London. 5, 179186.

Dueck, D., (1999). The Date and Method of Composition of Strabo's "Geography". Hermes. 127, 4, 467-478.

Garstang, J., (1943). Hittite Military Roads in Asia Minor: A study in Imperial Strategy with a Map. American Journal of Archaeology. 47, $1,35-62$.

Koelsch, W., A., (2004). Squinting Back at Strabo. Geographical Review. 94, 4, 502-518.

Ksenophon, (1998). Anabasis (Translated by: Tanju Gökçöl). İstanbul: Sosyal Yayınlar.

Lane, E., N., (1975). Two Notes on Lydian Topography. Anatolian Studies. 25, 105-110.

Macquenn, J., G., (1968). Geography and History in Western Asia Minor in the Second Millennium B.C. Anatolian Studies. 18, 169-185.

Pothecary, S., (2002). Strabo, the Tiberian Author: Past, Present and Silence in Strabo's "Geography". Mnemosyne. 4, 55, 4, 387-438.

Richards, G., C., (1941). Strabo. The Anatolian Who Failed of Roman Recognition. Greece\&Rome. 10, 29, 79-90.

Ridgeway, W., (1888). Contributions to Strabo's Biography. The Classical Review. 2, 3, 84.

Sayce, A., H., (1923). The Early Geography of South-Eastern Asia Minor. The Journal of Hellenic Studies. 43, 1, 44-49. 
Sevin, V., (2001). Anadolu'nun Tarihi Coğrafyası 1. Ankara: Türk Tarih Kurumu Basımevi.

Smith, W., (1854). Dictionary of Greek and Roman Geography (in two volumes). Boston: Little Brown and Company.

Sterrrett, J., R., S., (1888). The Wolfe Expedition to Asia Minor. Boston: Demrel and Upham.

Strabon, (2012). Geographika. (Translated by: Adnan Pekman). İstanbul: Arkeoloji ve Sanat Yayınları.

Vliet, E., C., L., (2003). The Romans and Us: Strabo's "Geography" and the Construction of Ethnicity. Mnemosyne. 4, 56, 3, $257-272$.

Wagstaff, J., M., (1987). Colonel Leake and the Classical Topography of Asia Minor. Anatolian Studies. 37, 23-35. 